\title{
Conversion of inverting glycoside hydrolases into catalysts for synthesizing glycosides employing a glycosynthase strategy
}

\author{
グライコシンターゼ化による反転型加水分解酵素の \\ グリコシド合成触媒への変換 \\ Kitaoka, Motomitsu' ${ }^{1}$ Honda, Yuji ${ }^{1,2}$; Fushinobu, Shinya ${ }^{3}$; \\ Hidaka, Masafumi ${ }^{1,3}$; Katayama, Takane ${ }^{2}$; and Yamamoto, Kenji ${ }^{4}$ \\ ${ }^{1}$ National Food Research Institute, National Agriculture and Food Research Organization, \\ Tsukuba, Ibaraki 305-8642, Japan \\ ${ }^{2}$ Ishikawa Prefectural University, Nonoichi, Ishikawa 921-8836, Japan \\ ${ }^{3}$ Department of Biotechnology, The University of Tokyo, Bunkyo-ku, Tokyo 113-8657, Japan \\ ${ }^{4}$ Division of Integrated Life Science, Graduate School of Biostudies, Kyoto University, \\ Sakyo-ku, Kyoto 606-8502, Japan \\ Fax: 81-29-838-7321, E-mail: mkitaoka@affrc.go.jp
}

(Received on December 22, 2008, accepted on January 14, 2009)

\begin{abstract}
Key Words: glycosynthase, inverting hydrolase, glycosylfuoride, Hehre resynthesis-hydrlysis mechanism, reducing end xylose-releasing exo-oligoxylanase, $\alpha$-fucosidase
\end{abstract}

\begin{abstract}
Reducing-end xylose-releasing exo-oligoxylanase (Rex, EC. 3.2.1.156) is an inverting xylanolytic enzyme, belonging to the glycoside hydrolase $(\mathrm{GH})$ family 8 , which hydrolyzes xylooligosaccharides to release xylose $\left(\mathrm{X}_{1}\right)$ from its reducing end. Rex hydrolyzes $\alpha$-xylobiosyl fluoride $\left(\alpha-\mathrm{X}_{2} \mathrm{~F}\right)$ to yield xylobiose $\left(\mathrm{X}_{2}\right)$ only in the presence of $\mathrm{X}_{1}$, confirming the Hehre resynthesis-hydrolysis mechanism. A library of mutant Rex at the catalytic base (D263) was constructed by saturation mutagenesis, in which D263C accumulated the highest level of xylotriose $\left(\mathrm{X}_{3}\right)$ from $\alpha-\mathrm{X}_{2} \mathrm{~F}$ and $\mathrm{X}_{1}$. However, $\mathrm{F}^{-}$releasing activities of the mutants were much less than that of the wild type. Next, Y198 residue of Rex that forms a hydrogen bond with nucleophilic water was substituted with phenylalanine, causing a marked decrease in hydrolytic activity and a small increase in the $\mathrm{F}^{-}$releasing activity from $\alpha-\mathrm{X}_{2} \mathrm{~F}$ in the presence of $\mathrm{X}_{1}$. Y198F of Rex accumulated more product during the glycosynthase reaction than D263C. Recently, an inverting $\alpha$-1,2-fucosidase belonging to GH95 was converted into glycosynthase by mutating a catalytic base residue. In both cases, the catalytic base should be intact.
\end{abstract}

\section{A. Introduction}

Enzymatic synthesis of glycosides (1-6) is a key topic in glycotechnology and does not require complicated organic synthesis procedures such as selective protection
要 約

還元末端キシロース遊離エキソオリゴキシラナーゼ （Rex, EC. 3.2.1.156）は, 糖加水分解酵素ファミリー8に属 する反転型キシラン分解醳素であり, キシロオリゴ糖から還 元末端キシロース $\left(\mathrm{X}_{1}\right)$ を遊離する反応を触媒する。Rex は $\mathrm{X}_{1}$ の存在下のみ, $\alpha$ キシロビオシルフルオリド $\left(\alpha-\mathrm{X}_{2} \mathrm{~F}\right)$ を 加水分解する, Hehre-合成一加水分解反応を示した。一般塩基 触媒残基（D263）变異酵素ライブラリーを作製し，グライコ シンターゼ活性により $\alpha-\mathrm{X}_{2} \mathrm{~F}$ と $\mathrm{X}_{1}$ からキシロトリオース $\left(\mathrm{X}_{3}\right)$ を最も良く蓄積する $\mathrm{D} 263 \mathrm{C}$ 変異醉素を選抜した。しか しながら，D263Cのフッ素イオン遊離活性は親酵素より低か った。次に, 一般塩基触媒残基と共に求核試薬である水を保 持している残基である Y198 をフェニルアラニンに変異させた ところ, フッ素イオン遊離活性が低下寸ることなく加水分解 活性のみに大幅に低下が見られた。Rex の Y 1 198F 変異酵素は $\mathrm{D} 263 \mathrm{C}$ よりも $\mathrm{X}_{3}$ の蓄積が多かった。最近になり, 糖加水分 解酵素ファミリー 95 に属する $\alpha 1,2$ フコシダーゼのグライコ シンターゼ化が報告された。この場合は, 一般塩基触媒残基 と相互作用している別の残基に変異を入れることが有効であ った。両者ともに, 一般塩基触媒残基は変異させない方が良 かった。

A. はじめに

グリコシドの有機合成において, 水酸基の選択的保護 · 脱保護は最も煩雑なステップである。酵素を用いたグリコシ 


\section{Retaining GHs}

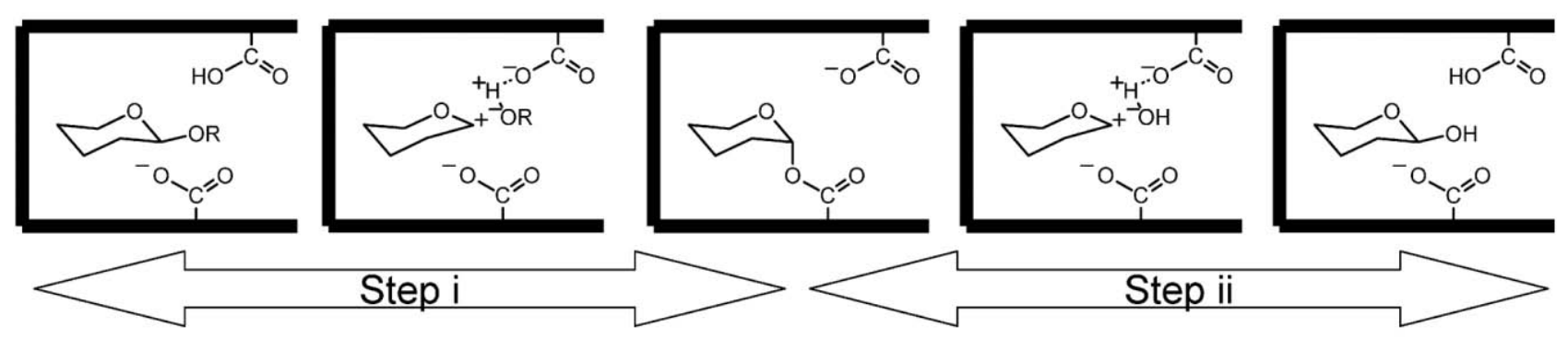

\section{Inverting GHs}

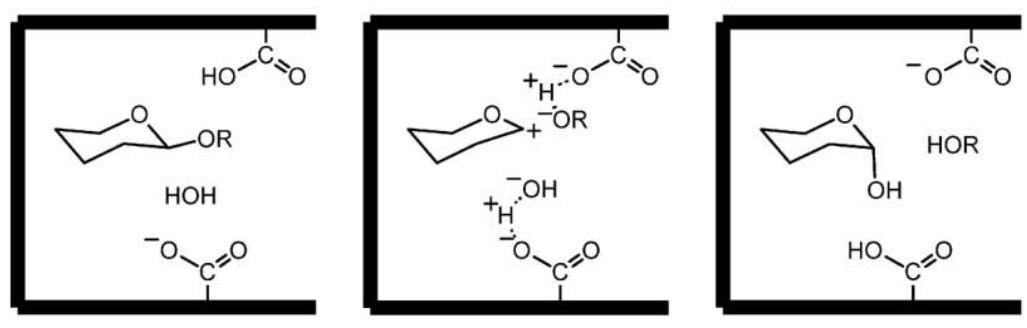

Fig. 1. Typical reaction mechanisms of retaining and inverting glycoside hydrolases (GHs).

and deprotection of the hydroxyl group. Utilization of hydrolytic enzymes such as glycoside hydrolase, $(\mathrm{GH})$ in glycotechnology is expected due to their wide variations. GHs are generally categorized into two types, retaining and inverting enzymes, based on changes in the anomeric configurations during GH reactions (7-11). Typical reaction mechanisms of both types are similar and use two acidic residues acting as a general acid (a proton donor) and a general base (a nucleophile) as illustrated in Fig. 1. The retaining GH reaction proceeds in two steps: (i) the general acid residue donates a proton to the glycosyl oxygen atom and the base residue directly attacks the anomeric center in concert, producing a covalent-bound intermediate at the base residue with a Walden inversion; and (ii) the intermediate undergoes another inverting hydrolysis resulting in anomeric retention during the overall reaction. The inverting GH reaction differs in that the nucleophilic reagent attacks the anomeric center. In this case, a water molecule, activated by the base residue, attacks the anomeric center to hydrolyze the glycoside with anomeric inversion.

Many retaining GHs are utilized in the production of various glycosides including commercial production, using their transglycosylation activity (12). However, none of the inverting GHs show transglycosylation activity. The
ド合成 (1-6) は, 往々にしてこれら選択的保護 - 脱保護のステ ップを回避することができるため, 糖鎖工学の重要な要素の 一つに数えられる。なかでも糖加水分解酵素 $(\mathrm{GH})$ は多くの 基質特異性を示す酵素が知られているため, 糖鎖合成への応 用が期待されている。 $\mathrm{GH}$ は反応前後のアノマー型の変化に より保持型および反転型に大別される(7-11)。両者の反応 は, 一般酸触媒（プロトン供与体）打よび一般塩基触媒（求 核体）として働く2つの酸性アミノ酸残基の協調作用により 触媒されていることは共通している（図 1)。保持型加水分解 酵素の反応は以下の二段階により, グリコシド結合と同じア ノマー型の生成物を生じる：(ステップ i ）一般酸触媒残基が グリコシド結合の酸素原子にプロトンを供与するとともに, 一般塩基触媒残基がアノメリック炭素を直接求核攻撃するこ とによる，Walden 反転を伴う一般塩基触媒残基と共有結合し た中間体の形成，（ステップii）共有結合中間体の Walden 反 転を伴う加水分解。反転型加水分解酵素の場合は, 保持型酵 素々比較して求核試薬が異なる。この場合は，一般塩基触媒 残基により活性化された水分子がアノマー炭素を求核攻撃す ることによりアノマー反転を伴った加水分解を完結する。

多くの保持型加水分解䤉素は糖転移反応によるグリコシ ド合成に用いられて抢り，工業化されている例もある(12)。 しかしながら, 反転型加水分解酵素は糖転移活性を示さな 
difference in the occurrence of transglycosylation is due to a mechanistic difference (Fig. 1). In the case of a retaining $\mathrm{GH}$, if the glycosyl-enzyme intermediate is attacked by another alcohol instead of water, transglycosylation occurs. It should be noted that no water molecules participate in this reaction. Considering the transglycosylation reaction by an inverting $\mathrm{GH}$, the inclusion of a dehydration step must be postulated because the reaction is initiated by hydration of the glycosyl linkage. Because the enzymatic reaction must be performed in water, the presence of abundant water molecules prohibits the dehydration step resulting in no transglycosylation. Thus, usages of inverting GHs are limited in hydrolysis, not the production of glycosides by transglycosylation. In this mini-review, a strategy to convert an inverting GH into a catalyst for the syntheses of glycosides is described.

\section{B. The Hehre resynthesis-hydrolysis reaction}

Hehre and co-workers reported interesting phenomena associated with inverting GHs. Previously, they reported that $\beta$-amylase, an inverting GH, hydrolyzed $\alpha$ - and $\beta$-maltosyl fluorides to maltose and $\mathrm{F}^{-}$(13). It should be noted that $\beta$-maltosyl fluoride possesses the opposite anomeric configuration of the normal substrates that are hydrolyzed by the enzyme. Later, various inverting enzymes were found to hydrolyze the so called "wrong" glycosyl fluorides as shown in Table 1 (14-20), suggesting that the reaction is common among inverting GHs (Fig. 2). Instead of simple hydrolysis, the reaction mechanism consists of two steps. In the first step, a new glycoside of the correct anomer forms from the wrong glycosyl fluoride and an acceptor through a Walden inversion. The new glycoside is then hydrolyzed with an anomeric inversion at the same site on the enzyme before it is released from the active center, i.e., the normal reaction of an inverting GH. The mechanism was confirmed by analyzing the reaction of trehalase, which hydrolyzes the
い。糖転移反応の有無は反応機構の違いから説明できる（図 1)。保持型加水分解酵素の場合は, 共有結合中間体が水では なく他のアルコールにより攻撃されれば糖転移反応になる。 ここで注目すべきは反応経路に水分子の関与がない点であ る。一方反転型酵素は，グリコシド結合の水和により反応が 始まるため，糖転移反応を仮定すると脱水反応を仮定する必 要がある。しかしながら, 糖加水分解酵素の反応は水溶液中 で行われるために, 大量の水分子の存在により脱水反応は事 実上起こりえない。以上の理由により反転型加水分解酵素は 原理的に糖転移反応を示さず，それらの応用も加水分解に限 られていた。本稿では反転型加水分解酵素のグリコシド結合 合成触媒への変換について解説する。

\section{B. Hehre-再合成一分解反応}

Hehre らは 1970 年代に反転型加水分解酵素による興味深 い現象を報告している。この現象は $\beta$ アミラーゼによる， $\alpha-$ および $\beta$-マルトシルフルオリドのマルトースとフッ素イオン への加水分解として最初に報告された $(13)$ 。ここで注目すべ きは， $\beta$-マルトシルフルオリドのアノマー型は $\beta$ アミラーゼ の切断する基質のアノマー型とは逆である点である。後に種 々の反転型加水分解酵素が “間違った” フッ化グリコシドを 加水分解することが報告され（表 1）（14-20），この現象は反 転型加水分解酵素に一般的に見られることが示された(図 2)。 この反応は単純な加水分解ではなく, 二段階の反応による。 第一段階では, 加水分解酵素の基質となりうるグリコシド が，“間違った”グリコシルフルオリドとアクセプター分子か ら Walden 転位を伴い合成される。合成されたグリコシドは 酵素の良い基質であるため, 酵素の活性中心から出る前に直 ちに反転型加水分解を受ける。この反応機構は $\alpha-1, \alpha-1$ 結合 を反転型に加水分解する酵素であるトレハラーゼを用いて証 明された (20)。この反応機構は後にHehre-再合成一分解機構

Table 1. List of enzymes reported to exhibit the Hehre resynthesis-hydrolysis reaction

\begin{tabular}{|c|c|c|c|c|c|}
\hline Enzyme & Family & $\begin{array}{l}\text { Glycoside } \\
\text { hydrolyzed }\end{array}$ & Wrong fluoride used & $\begin{array}{l}\text { Donor acts } \\
\text { as acceptor }\end{array}$ & references \\
\hline$\beta$-amylase & (GH14) & $\alpha$-maltoside & $\beta$-maltosyl fluoride & yes & 13 \\
\hline trehalase & Not assigned & $\alpha$-glucoside & $\beta$-glucosyl fluoride & no & 19,20 \\
\hline$\beta$-xylosidase & Not assigned & $\beta$-xyloside & $\alpha$-xylosyl fluoride & yes & 18 \\
\hline$\alpha$-1,2-fucosidase & GH95 & $\alpha$-fucoside & $\beta$-fucosyl fluoride & no & 83 \\
\hline
\end{tabular}

\footnotetext{
* reducing-end-xylose releasing exo-oligoxylanase
} 
A.

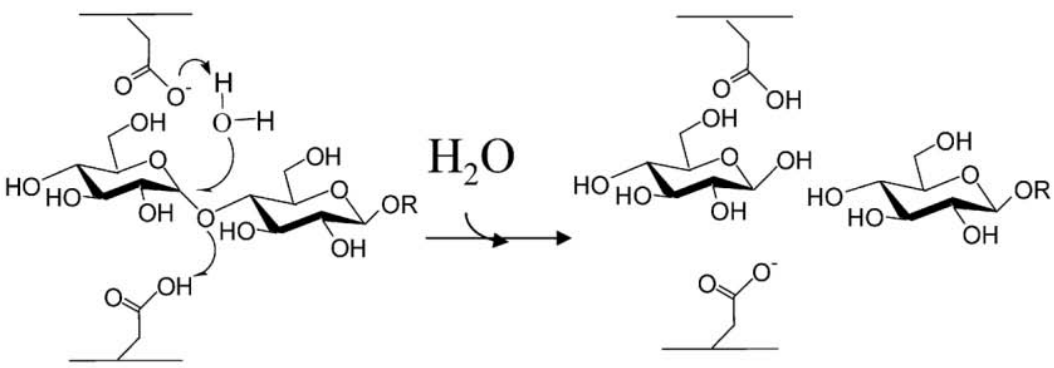

B.

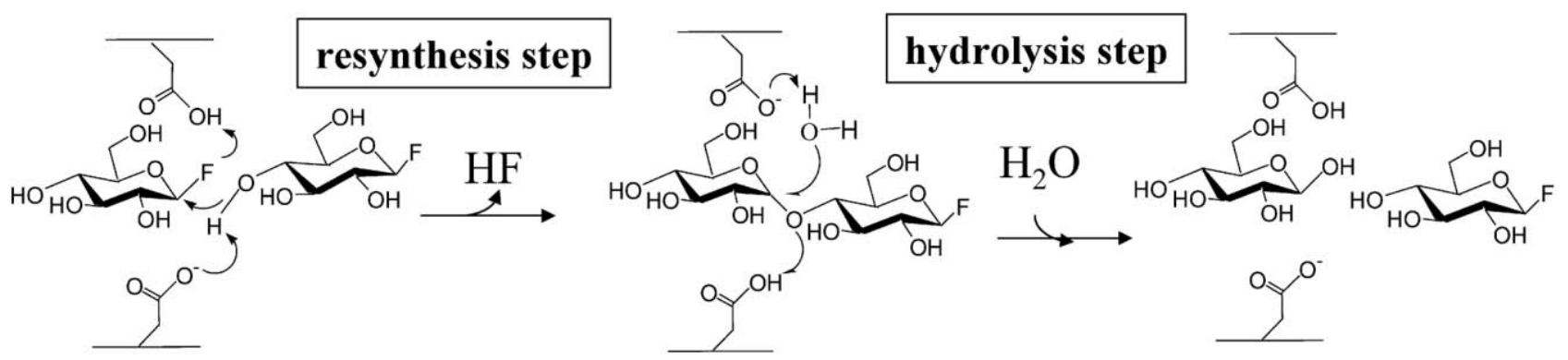

Fig. 2. The Hehre resynthsis-hydrolysis reaction. A. The reaction mechanism of inverting $\mathrm{GH}$ described as glucoamylase. B. The reaction mechanism of the Hehre resynthesishydrolysis reaction.

$\alpha-1, \alpha-1$ linkage with anomeric inversion (20). This mechanism was later named the "Hehre resynthesishydrolysis mechanism" $(14,15)$.

The Hehre resynthesis-hydrolysis mechanism is often difficult to detect because many enzymes recognize glycosyl fluoride not only as a donor but also as an acceptor $(13-15,18,21,22)$, such as $\beta$-maltosyl fluoride for $\beta$ amylase and $\beta$-glucosyl fluoride for glucoamylase. However, reliable experimental evidence for this mechanism was reported for trehalase using $\beta$-glucosyl fluoride as the donor and glucose or xylose as the acceptor $(19,20)$. In that case, the reactions were performed at $0^{\circ} \mathrm{C}$ to avoid spontaneous hydrolysis of $\beta$-glucosyl fluoride, which generated glucose as the acceptor molecule.

\section{Glycosynthase}

The mutant GHs that catalyze the synthesis of glycosides from the glycosyl fluoride of the opposite anomer are called glycosynthases (Fig. 3). In 1998, Withers' group reported the first glycosynthase in which a mutant retaining enzyme, GH1 $\beta$-glucosidase from Agrobacterium sp., with a mutation of its nucleophilic
と命名された $(14,15)$ 。

多くの酵素では, グリコシルフルオリドがドナーとして だけでなくアクセプターとしても作用する $(13-15,18,21,22)$ 。 たとえば， $\beta$-マルトシルフルオリド抢よび $\beta$-グルコシルフル オリドはそれぞれ $\beta$ アミラーゼ抢よびグルコアミラーゼに対 してアクセプターとしても作用する。そのため, Hehre-再合 成一分解機構を実験的に証明することは困難である。反応機 構の実験的証拠は $\beta$-グルコシルフルオリドをドナー, グル コースあるいはキシロースをアクセプターとしたトレハラー ゼの反応解析により得られた $(19,20)$ 。この実験では $\beta$-グルコ シルフルオリドの非醖素的加水分解によるグルコース（アク セプターとして作用）の生成を避けるため反応は $0^{\circ} \mathrm{C} て ゙$ 行わ れた。

C. グライコシンターゼ

反対のアノマー型のグリコシルフルオリドを基質として グリコシドを合成する変異加水分解酵素をグライコシンター ゼと呼ぶ（図 3)。最初の報告は 1998 年の Withers らによるも のである $(23,24)$ 。この報告では Agrobacterium sp. 由来の $\mathrm{GH} 1$ に属する $\beta$-グルコシダーゼの求核触媒残基（E358）を 

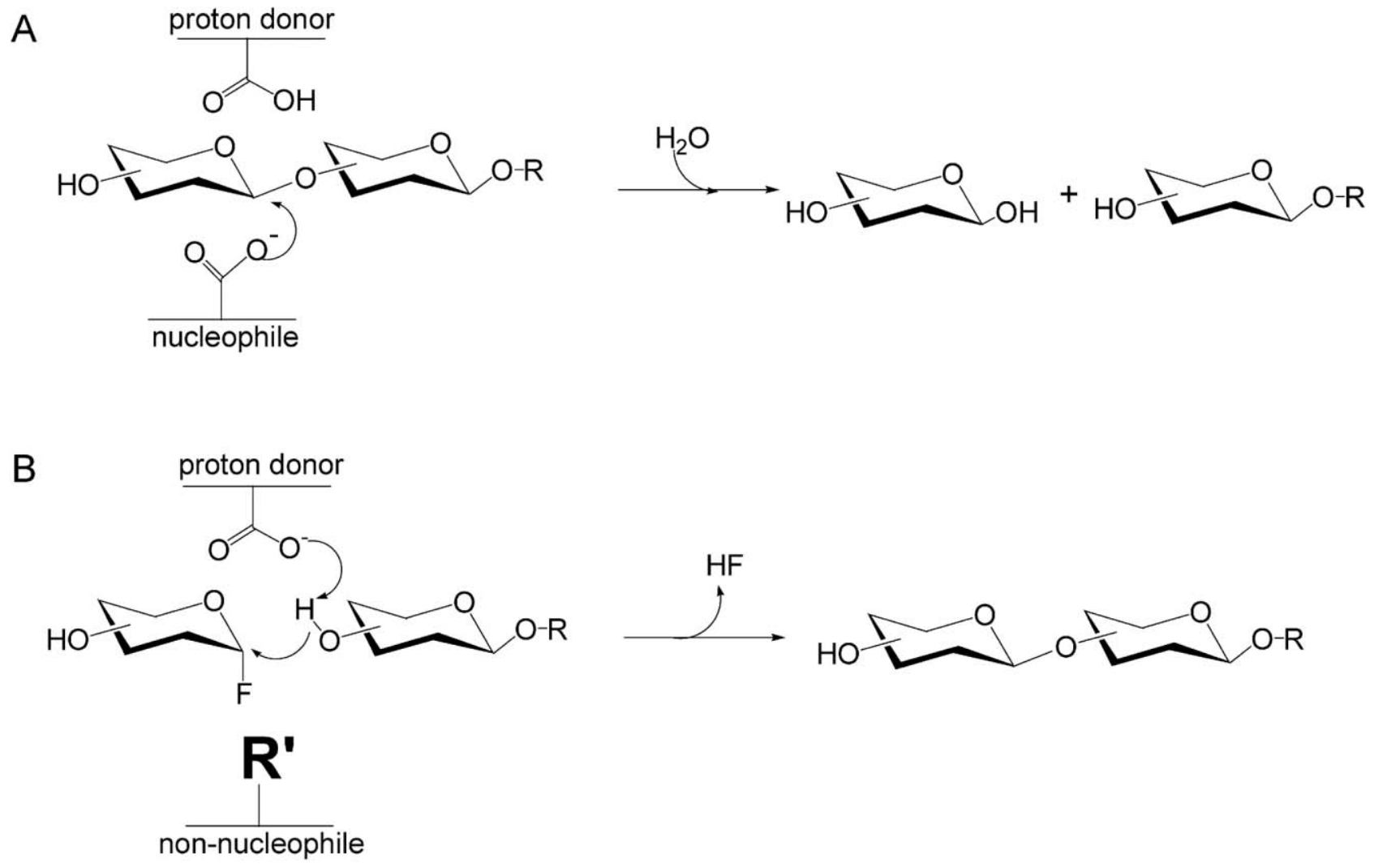

Fig. 3. Glycosynthase. A. Reaction of the wild type retaining glycoside hydrolase. B. Reaction of a glycosynthase mutant.

residue (E358), catalyzed the synthesis of various $\beta$-glucosides using $\alpha$-glucosyl fluoride as a donor and various 4nitrophenyl- $\beta$-glycosides as acceptors $(23,24)$. Since then, by substituting their nucleophilic residues, various retaining GHs have been converted into glycosynthases as summarized in Table $2(15,23-68)$.

Williams and Withers commented that the glycosynthase technique was developed by mimicking the Hehre resynthesis-hydrolysis mechanism of inverting GHs (15). However, derivatization to glycosynthase has been a technology for retaining GHs only, and no glycosynthase derived from an inverting $\mathrm{GH}$ has been reported.

\section{A model of inverting GH Reducing end xylose-releas- ing exo-oligoxylanase (Rex) (69-71)}

GH8 is a family of inverting hydrolases whose members are mainly cellulase and chitosanase. In addition, endo $\beta-1,4$ xylanase ( $\mathrm{pXyl}$ ), belonging to this family, was found in a culture supernatant of Pseudoalteromonas haloplanktis and characterized (72). The three dimensional structures of two GH8 enzymes were found to have an $(\alpha / \alpha)_{6}$ barrel structure (clan GH-M) $(73,74)$. The GH8
不活性な残基に置換することにより， $\alpha$-グルコシルフルオリ ドをドナー，4-ニトロフェニルグリコシドをアクセプターと して種々の $\beta$-グルコシドを合成している。その後, 表 2 に示 すように多くの保持型加水分解酵素が求核触媒残基を变異さ せることによりグライコシンターゼに変換されている $(15,23-$ $68)$ 。

Williams と Withers は，グライコシンターゼは反転型加 水分解醉素に見られる Hehre-再合成一分解機構を元に設計し たとコメントしている(15)。しかしながら，本稿で述べる報 告以前にはすべてのグライコシンターゼは保持型加水分解酵 素を起原とするものであった。

D. 還元末端キシロース遊離エキソオリゴキシラナーゼ (Rex)：モデルとなる反転型加水分解酵素 (69-71)

GH8 は, 主にセルラーゼとキトサナーゼから構成される 反転型加水分解醥素のファミリーである。加えて, Pseudoalteromonas haloplanktis 由来エンド $\beta 1,4$-キシラナーゼ （pXyl）が報告された $(72)$ 。GH8 酵素の立体構造は $(\alpha / \alpha)_{6}$ バ レル構造（clan GH-M）であることが同定された $(73,74)$ 。唯 一の GH8 キシラナーゼである $\mathrm{pXyl}$ は，ゲノム既読好アル 
Table 2. List of reported glycosynthases and their origins

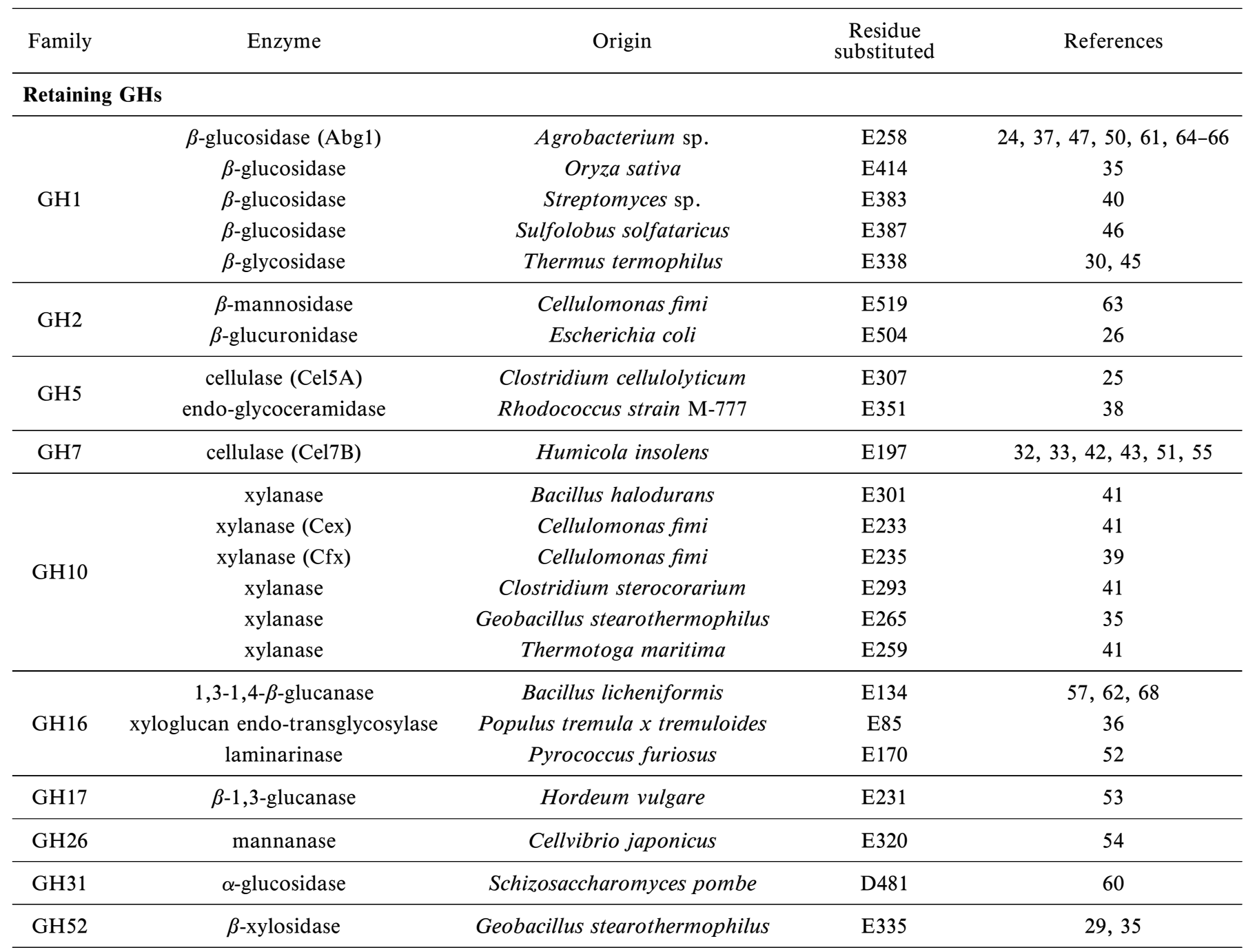

Inverting GHs (described in this mini-review)

\begin{tabular}{ccccc}
\hline GH8 & Rex* & Bacillus halodurans & D263, Y198** & 77 \\
\hline GH95 & $\alpha$-1,2-fucosidase & Bifidobacterium bifidum & D766** & 83 \\
\hline
\end{tabular}

* reducing end xylose-releasing exo-oligoxylanase

** residue other than the catalytic base

xylanase, pXyl, has the highest amino acid identity (32.6 $\%)$ with the protein encoded by the BH2105 gene (GenBank accession number: BAB05824) of Bacillus halodurans $\mathrm{C}-125$, an alkalophilic bacterium whose genomic sequence is available $(72,75)$.

The recombinant $\mathrm{BH} 2105$ protein did not hydrolyze birch wood xylan as well as any other polymeric substrate for GH8 enzymes (chitosan, lichenan, curdlan, and carboxymethyl cellulose). Various pentasaccharides, including xylopentaose, cellopentaose, laminaripentaose,
カリ性細菌Bacillus halodurans $\mathrm{C}-125$ の $\mathrm{BH} 2105$ 遺伝子の コードする蛋白と最も高いアミノ酸配列相同性（32.6\%）を 示した $(72,75)$ 。

$\mathrm{BH} 2105$ タンパクは重合度 3 以上のキシロオリゴ糖（ $\left.\mathrm{X}_{\mathrm{n}}\right)$ に作用し初期に $\mathrm{X}_{1}$ と $\mathrm{X}_{\mathrm{n}-1}$ を生じ, 最終的に $\mathrm{X}_{1}$ と $\mathrm{X}_{2}$ にまで 分解した。本酵素はキシロビオース $\left(\mathrm{X}_{2}\right)$ をほとんど分解し なかった。また，本酵素は 4-ニトロフェニル $\beta$-キシロシドお よびキシロビオシドを全く分解しなかった。通常の反転型加 
chitopentaose, and chitosanpentaose, were used as substrates and the enzyme showed hydrolytic activity only on xylopentaose $\left(\mathrm{X}_{5}\right)$, initially producing $\mathrm{X}_{1}$ and $\mathrm{X}_{4}$, and then $X_{1}$ and $X_{2}(71)$. It hydrolyzed xylooligosaccharides $\left(X_{n}\right)$ releasing $X_{1}$ and $X_{n-1}$ from $X_{n}$ in the initial stage when $n \geq 3$, but hardly hydrolyzed $X_{2}$. On the other hand, the enzyme exhibited no activity on 4-nitrophenyl- $\beta$-xyloside and 4-nitrophenyl- $\beta$-xylobioside. The enzyme had no transglycosidation activity as well as other inverting enzymes. It only hydrolyzed Glc-Xyl-Xyl, Xyl-Xyl-Glc, and Glc-Xyl-Glc from a range of $\beta-1,4$ linked D-glucose and D-xylose-based trisaccharides (76) at a much lower rate than $\mathrm{X}_{3}$. The reducing end specificity was confirmed based on their products. The reducing end specificity is completely different from that of $\beta$-xylosidase, which liberates xylose from the non-reducing end.

Considering the above results, GH8 glycosidase from $B$. halodurans $\mathrm{C}-125$ was assigned as a new class of enzyme and called reducing end xylose-releasing exooligoxylanase (Rex). The enzyme reaction is clearly different from that of $\beta$-xylosidase, and it has been registered as a new enzyme, EC 3.2.1.156, in the Enzyme Nomenclature (http://www.chem.qmul.ac.uk/iubmb/enzyme/).

The crystal structures of Rex in unliganded and complex forms at 1.35-2.204 Å resolution (PDB accession
水分解酵素と同様に糖転移活性は検出されなかった。本酵素 は，グルコースおよびキシロースが $\beta 1,4$ 結合した構造の三糖 ライブラリー(76)のうち, Glc-Xyl-Xyl, Xyl-Xyl-Glc および Glc-Xyl-Glc のみ $\mathrm{X}_{3}$ より遅い速度で分解した。これらの分解 産物から, 還元末端の単糖を遊離していることが証明され た。還元末端からのキシロース遊離は, 非還元末端からキシ ロースを遊離する酵素である $\beta$-キシロシダーゼとは全く異な る酵素であることを示している。

以上の結果から，B. halodurans $\mathrm{C}-125$ 由来 $\mathrm{GH} 8$ 酵素は 新規酵素, 還元末端キシロース遊離エキソオリゴキシラナー ゼ（Rex）と同定された。反応は $\beta$-キシロシダーゼとは全く 異なり，本酵素活性は Enzyme Nomenclature（http://www. chem.qmul.ac.uk/iubmb/enzyme/）にEC 3.2.1.156 として登 録された。

基質非結合抢よび結合状態の Rex の X 線結晶構造解析を 行い, 分解能 1.35-2.20 ̊の構造 (PDB accession Number: 1WU4, 1WU5, 1WU6）を得た。その結果, Rexは-2から+1 までの 3 つのサブサイトを持つことが示唆された $(69)$ 。 Rex の構造は $(\alpha / \alpha)_{6}$ バレル構造からなる GH8 エンドキシラナー ゼである pXyl（73）と類似していた（図 4)。触媒セットも Rex と $\mathrm{pXyl}$ の間で良く保存されていた。最も大きな相違点は基質
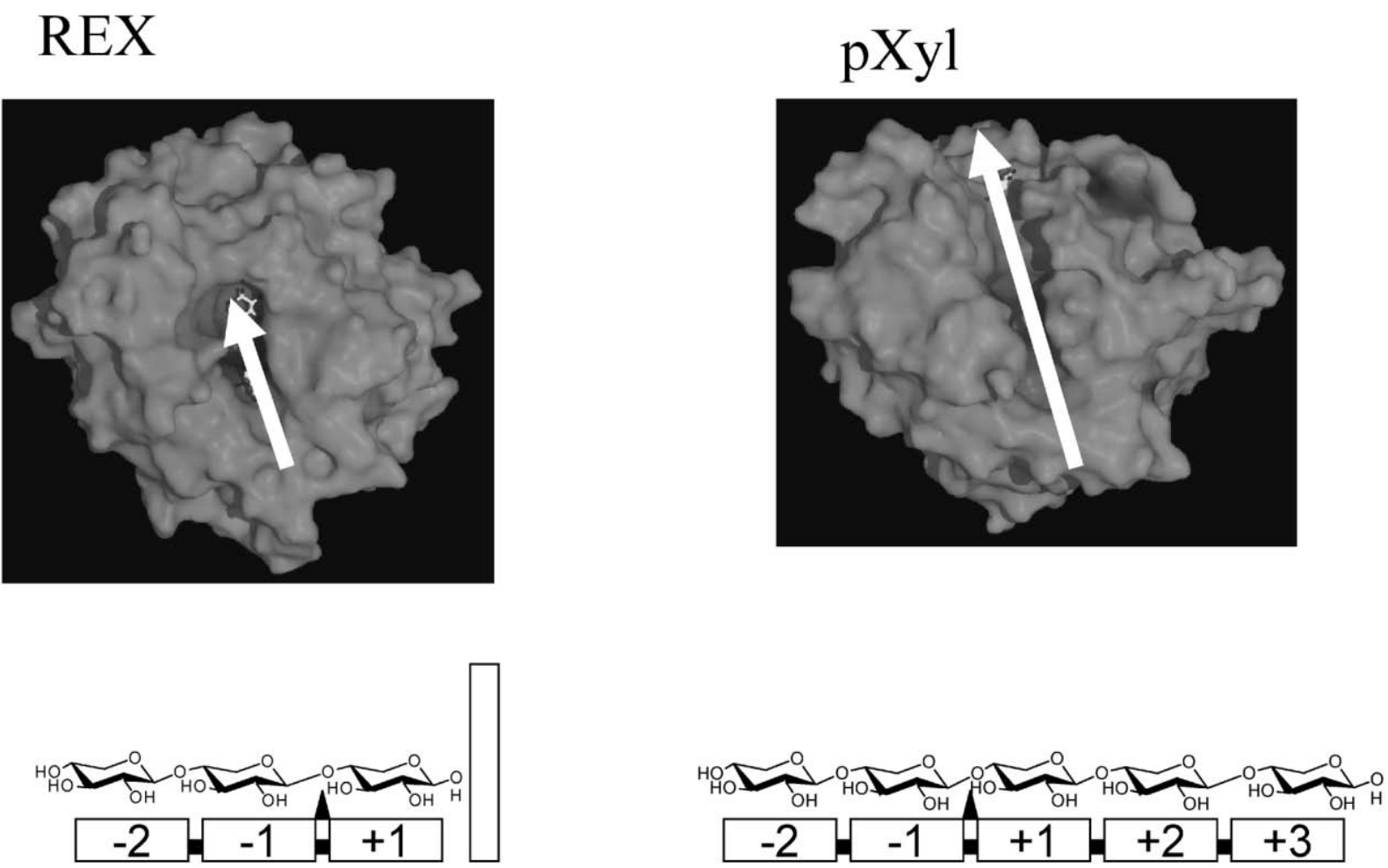

Fig. 4. Comparison of the structures and the subsite models of Rex and pXyl. The substrate binding grooves are indicated with arrows. 
numbers: 1WU4, 1WU5, and 1WU6) revealed the structural aspects of three Rex subsites ranging from -2 to +1 (69). The structure of Rex is very similar to that of $\mathrm{pXyl}$ (73), the GH8 endo-xylanase composed of an $(\alpha / \alpha)_{6}$ barrel structure (Fig. 4). The catalytic machinery of Rex is well conserved in pXyl. The most significant difference in the structures of Rex and pXyl was found at the binding cleft. The position corresponding to subsite +2 of Rex is blocked by a barrier formed by a kink in the loop before helix $\alpha_{10}$, and $\mathrm{H} 319$ in the loop forms a direct hydrogen bond with the $\beta$-hydroxyl of xylose residue bound at subsite +1 , contributing to the specific recognition of the reducing end xylose.

\section{E. Conversion of Rex into glycosynthase}

\section{E-1. Hehre resynthesis-hydrolysis of Rex (77)}

Rex is considered to be a suitable enzyme for examining the Hehre resynthesis-hydrolysis mechanism. As Rex hydrolyzes $\mathrm{X}_{3}$ to release $\mathrm{X}_{1}$ from the reducing end, it is expected to utilize $\alpha$-xylobiosyl fluoride $\left(\alpha-\mathrm{X}_{2} \mathrm{~F}\right)$ as the donor and $\mathrm{X}_{1}$ as the acceptor. It should be mentioned that $\mathrm{X}_{2}$, the hydrolytic product of $\alpha-\mathrm{X}_{2} \mathrm{~F}$, never acts as the acceptor molecule due to the reducing end exo-specificity. Thus, the spontaneous hydrolysis of $\alpha-\mathrm{X}_{2} \mathrm{~F}$ does not affect the reaction significantly, and the donor and acceptor are considered to be completely independent during the reaction (Fig. 5A).

Initially, the action of the wild type Rex on $\alpha-\mathrm{X}_{2} \mathrm{~F}$ $(20 \mathrm{mM})$ in both the presence and absence of $\mathrm{X}_{1}(20 \mathrm{mM})$ were examined. The enzyme was inactive on $\alpha-\mathrm{X}_{2} \mathrm{~F}$ in the absence of $\mathrm{X}_{1}$, but produced $\mathrm{X}_{2}$ from $\alpha-\mathrm{X}_{2} \mathrm{~F}$ in the presence of $\mathrm{X}_{1}$ (Fig. 5B). These results suggest that the reaction was not a simple hydrolysis of $\alpha-\mathrm{X}_{2} \mathrm{~F}$, but was a Hehre resynthesis-hydrolysis. No $\mathrm{X}_{3}$ was detected during the reaction suggesting that most of the resulting $X_{3}$ would be hydrolyzed into $X_{1}$ and $X_{2}$ before it escaped from the active center because $X_{3}$ was generated at the same position where it was hydrolyzed.

\section{E-2. Mutation of the base residue (77)}

First, the base residue, D263, was mutated to convert Rex into glycosynthase following the same procedure used for the retaining GHs. A saturation mutagenesis library of Rex at position D263, regarded as D263X, was constructed and from this mutant library, 120 colonies were randomly selected and each mutant enzyme was purified by His-tag affinity column chromatography. During the screening for $\alpha-\mathrm{X}_{2} \mathrm{~F}$-consuming activity in the presence of $X_{1}$ and accumulation of $X_{3}$ by a TLC analysis, 71 of the 120 proteins exhibited activity. Nine types of D263X mutants were found in addition to the wild-type. The numbers of clones obtained were D (wild-type), 15; G, 22;
結合クレフトの構造に見られた。Rex のサブサイト +2 に相当 する場所は $\alpha_{10}$ ヘリックスの前のループのよじれにより塞がれ ており，またループ上の H319が＋1 に結合するキシロースの アノメリック $\beta$ 水酸基と直接水素結合を形成することにより 還元末端のキシロースを認識していた。

E. Rexのグライコシンターゼへの変換

E-1. Rex の Hehre-再合成一分解反応 (77)

Rex は Hehre-再合成一分解反応を解析するためには最も 都合の良い酵素と考えられた。 Rex の反応は $X_{3}$ を加水分解し て還元末端の $X_{1}$ を遊離するので，Hehre-再合成－分解反応で は $\alpha$ キシロビオシルフルオリド $\left(\alpha-\mathrm{X}_{2} \mathrm{~F}\right)$ をドナー, キシロー スをアクセプターにすると予想された。ここで重要なのは, 還元末端特異性から $\alpha-\mathrm{X}_{2} \mathrm{~F}$ やその非酵素的分解産物である $\mathrm{X}_{2}$ の両者ともアクセプターとして作用しないことである。その ため, 非酵素的加水分解は反応に影響を与えないため, ド ナーとアクセプターを容易に区別して扱うことが可能になる (図 5A)。

$\operatorname{Rex}$ の $\mathrm{X}_{1}(20 \mathrm{mM})$ 存在および非存在下における $\alpha-\mathrm{X}_{2} \mathrm{~F}$ $(20 \mathrm{mM})$ に対する反応を調べた。その結果， $\mathrm{X}_{1}$ 非存在下で は何も反応が見られなかったが， $\mathrm{X}_{1}$ 存在下では $\alpha-\mathrm{X}_{2} \mathrm{~F}$ から $\mathrm{X}_{2}$ を生じた（図 $5 \mathrm{~B}$ )。この結果は， $\alpha-\mathrm{X}_{2} \mathrm{~F}$ の分解が単なる加 水分解ではなく Hehre-再合成一分解反応によるものであるこ とを明確に示している。反応中間体として予想される $\mathrm{X}_{3}$ は検 出されなかった。これは, $\operatorname{Rex}$ の活性中心に生成した $\mathrm{X}_{3}$ は本 来 Rexの良い基質であるために直ちに加水分解されたものと 考えられた。

\section{E-2. 一般塩基触媒残基への变異導入 (77)}

Rex をグライコシンターゼに変換するために，まず保持 型加水分解酵素々同様に一般塩基触媒残基 D263 への変異を試 みた。D263 を任意のアミノ酸残基に変異させた飽和変異ライ ブラリーを作製し，ランダムに 120 クローンを選抜し Hisータ グ精製によりそれぞれ精製酵素を得た。 $\alpha-\mathrm{X}_{2} \mathrm{~F}$ と $\mathrm{X}_{1}$ を基質と したときの反応生成物を TLCにより確認し， $\alpha-\mathrm{X}_{2} \mathrm{~F}$ 消費活性 および $\mathrm{X}_{3}$ 蓄積活性のある変異酵素を選抜したところ，120 中 71 クローンに活性が確認された。それらのDNAをシーケン スした結果，以下の 9 種のアミノ酸置換が見いだされた。D (変異無し), 15; G, 22; A, 12; V, 8; T, 5; L, 3; N, 2; C, 2; P, 1; 
A

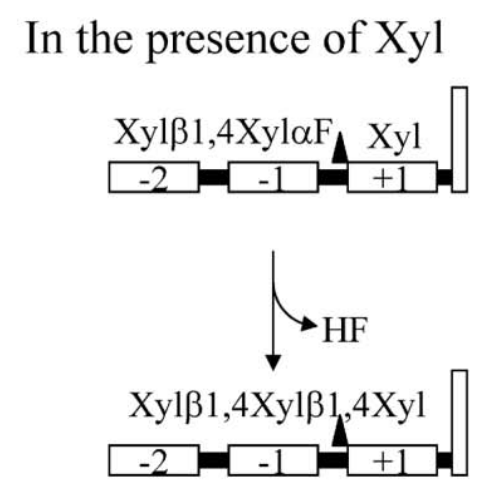

(Undetectable intermediate)

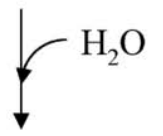

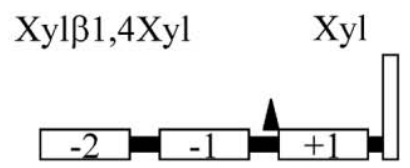

Hydrolysis of $\alpha-\mathrm{X}_{2} \mathrm{~F}$
B

In the absence of Xyl

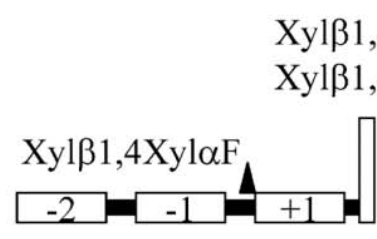

No reaction
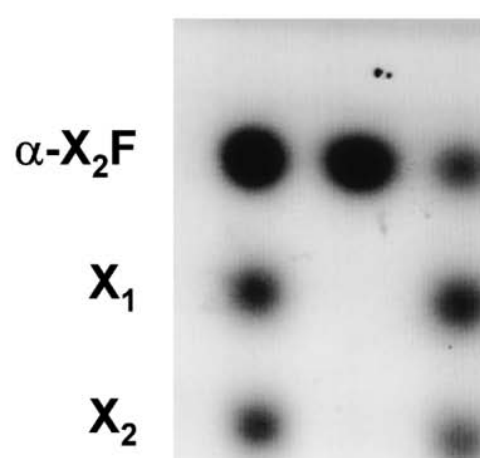

$x_{1}$

$\mathbf{X}_{2}$

$\mathbf{X}_{3}$

Std 12

Fig. 5. The Hehre resynthesis-hydrolysis reaction catalyzed by Rex. A: Expected reaction: Due to the reducing end-exo specificity, neither $\alpha-\mathrm{X}_{2} \mathrm{~F}^{-}$nor $\mathrm{X}_{2}$ is expected to enter the +1 subsite as the acceptor. B: Actual results: The $\alpha-\mathrm{X}_{2} \mathrm{~F}^{-}$reaction by the wild-type Rex was carried out in the absence (lane 1) and presence (lane 2) of $\mathrm{X}_{1}$ for $1 \mathrm{~h}$ with an enzyme concentration of $0.4 \mu \mathrm{M}$. Lane "Std" shows $\alpha-\mathrm{X}_{2} \mathrm{~F}, \mathrm{X}_{1}, \mathrm{X}_{2}$ and $\mathrm{X}_{3}$.

A, 12; V, 8; T, 5; L, 3; N, 2; C, 2; P, 1; and S, 1 . The wildtype exhibited the highest $\alpha-\mathrm{X}_{2} \mathrm{~F}$ consumption without accumulation of $\mathrm{X}_{3}$. Among the mutants, D263C exhibited the greatest production of $\mathrm{X}_{3}$ followed by D263N (Fig. 6). Thus, D263C and D263N were selected as targets for further analysis of glycosynthase properties.

The $\mathrm{F}^{-}$releasing activity using a concentration of $10 \mathrm{mM} \alpha-\mathrm{X}_{2} \mathrm{~F}$ in the presence of $10 \mathrm{mM} \mathrm{X}_{1}$, and the hydrolytic activities of the wild type and D263 mutants, using $2.6 \mathrm{mM} \mathrm{X}_{3}$ are summarized in Table 2. Both D263C and D263N showed approximately $10 \%$ of the $\mathrm{F}^{-}$releasing activity as compared to the wild type. The mutations caused marked decrease in hydrolytic activity $\left(4.5 \times 10^{-4}\right.$ for $\mathrm{D} 263 \mathrm{C}$ and $2.9 \times 10^{-3}$ for $\left.\mathrm{D} 263 \mathrm{~N}\right)$. It should be noted that the remaining hydrolytic activity of D263N was 6.4 times higher than that of $\mathrm{D} 263 \mathrm{C}$, whereas their $\mathrm{F}^{-}$releasing activities were almost identical, resulting in a difference in the ratio of $\mathrm{F}^{-}$releasing activity to hydrolytic activity (F/H ratio). Figure 7 shows the time courses for the $\alpha-\mathrm{X}_{2} \mathrm{~F}$ and $\mathrm{X}_{1}$ reactions by the enzymes. In the wild-type reaction, $\mathrm{F}^{-}$and $\mathrm{X}_{2}$ concentrations increased in parallel, but
$\mathrm{S} ， 1$ 。親酵素が最も高い $\alpha-\mathrm{X}_{2} \mathrm{~F}$ 消費活性を示したが， $\mathrm{X}_{3}$ 蓄積 活性は見られなかった。 $\mathrm{X}_{3}$ 蓄積活性は $\mathrm{D} 263 \mathrm{C}$ が最も高く,

続いては D263N であった（図 6)。そこで，この両変異酵素 に対して機能解析を行った。

親酵素打よび各变異酵素の $10 \mathrm{mM} \mathrm{X}_{1}$ 存在下の $10 \mathrm{mM} \alpha-$ $\mathrm{X}_{2} \mathrm{~F}$ からの $\mathrm{F}^{-}$遊離活性抢よび $2.6 \mathrm{mM}$ 濃度での $\mathrm{X}_{3}$ 分解活性 を表 3 に示した。 D263C および $\mathrm{D} 263 \mathrm{~N}$ ともに， $\mathrm{F}^{-}$遊離活性 は親酵素の約 $1 / 10$ であった。変異により大幅な加水分解活性 の低下が観察された $\left(\mathrm{D} 263 \mathrm{C}, 4.5 \times 10^{-4} ; \mathrm{D} 263 \mathrm{~N}, 2.9 \times 10^{-3}\right)$ 。 両変異酵素の $\mathrm{F}^{-}$遊離活性はほぼ同じであるが, $\mathrm{D} 263 \mathrm{~N}$ の残 存加水分解活性は D263C の 6.4 倍市るために, $\mathrm{F}^{-}$遊離活性 々加水分解活性の比 $(\mathrm{F} / \mathrm{H})$ に大きな違いが見られた。図 7 に親酵素抢よび両変異酵素による $\alpha-\mathrm{X}_{2} \mathrm{~F}$ 抢よび $\mathrm{X}_{1}$ を基質と した反応の経時変化を示した。親酵素は $\mathrm{F}^{-}$と $\mathrm{X}_{2}$ が等モル増 加するが $\mathrm{X}_{3}$ は全く検出されなかったが, 両変異酵素では $\mathrm{X}_{3}$ が検出された。D263N の場合は $\mathrm{X}_{2}$ 濃度が $\mathrm{X}_{3}$ 濃度よりも高 く, 合成反応活性よりも加水分解活性の方が高いことが示さ れた。対照的に D263C では $\mathrm{X}_{3}$ 濃度が $\mathrm{X}_{2}$ 濃度よりも高かった。 


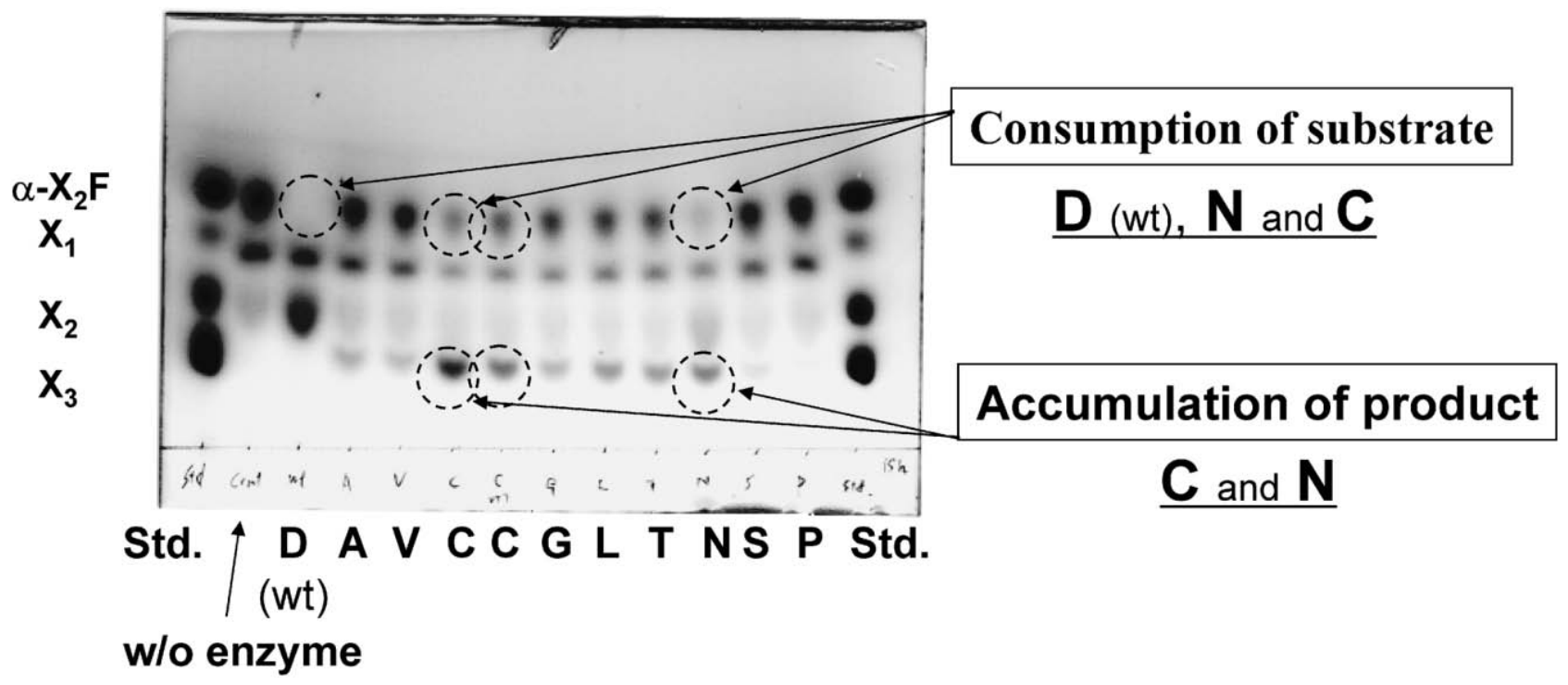

Fig. 6. Screening for the glycosynthase activity of D263 mutants. Each lane name indicates the residue substituted for D263; wild type indicated by wt.

Table 3. Activities of each mutant of Rex

\begin{tabular}{lccc}
\hline & $\mathrm{F}^{-}$release* $\left.^{*} \mathrm{~F}\right)$ & $\mathrm{X}_{3}$ hydrolysis** $(\mathrm{H})$ & $\mathrm{F} / \mathrm{H}$ ratio \\
\hline Wild type & 3.1 & 31.2 & 0.1 \\
D263C & 0.29 & 0.014 & 21 \\
D263N & 0.32 & 0.09 & 3.6 \\
Y198F & 4.7 & 0.06 & 78 \\
Y198F/D263C & 0.03 & 0.0006 & 50 \\
Y198F/D263N & 0.23 & 0.0016 & 144 \\
\hline
\end{tabular}

* $\mathrm{F}^{-}$releasing activitiy using the concentrations of $10 \mathrm{mM} \alpha-\mathrm{X}_{2} \mathrm{~F}$ and $10 \mathrm{mM} \mathrm{X}$. The values are given as $\mathrm{s}^{-1}$.

** Hydrolytic activity using $2.6 \mathrm{mM} \mathrm{X}_{3}$. The values are given as $\mathrm{s}^{-1}$.
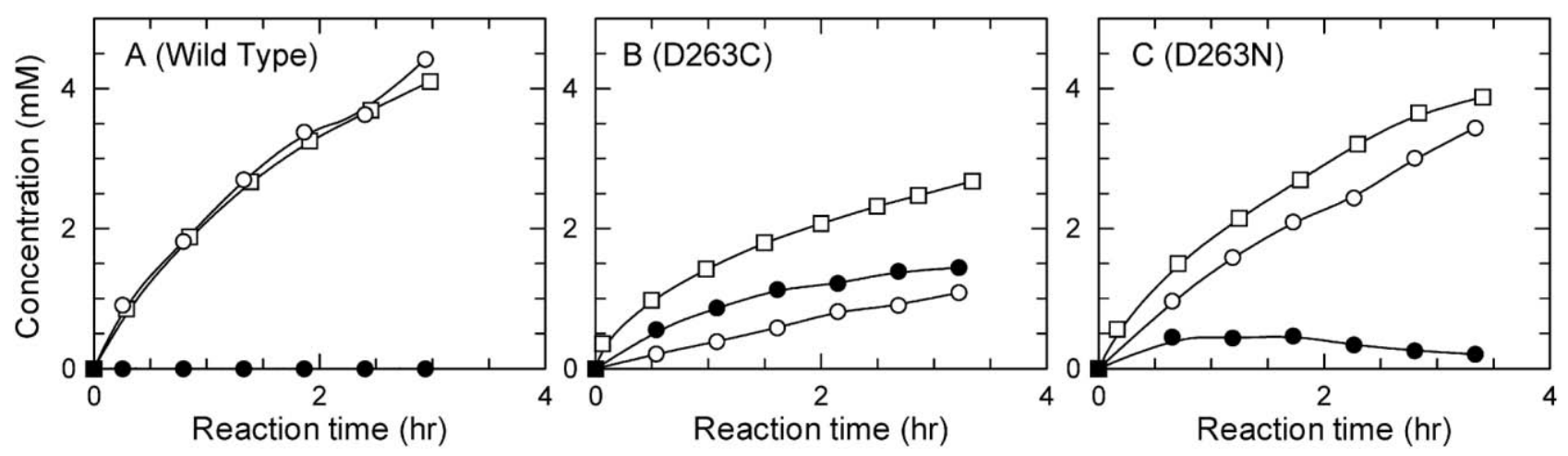

Fig. 7. Time courses for $\alpha-X_{2} F^{-}$and $X_{1}$ reactions. The enzymatic reaction was carried out in $0.1 \mathrm{M}$ MOPS buffer $(\mathrm{pH} 7.0)$ at $30^{\circ} \mathrm{C}$. Both substrate concentrations were $5.0 \mathrm{mM}$. A: Wild-type (enzyme concentration was $0.5 \mu \mathrm{M})$; B: Mutant D263C (7.2 $\mu \mathrm{M})$; C: Mutant D263N (7.3 $\mu \mathrm{M})$. Symbols indicate $\mathrm{F}^{-}$(open squares), $\mathrm{X}_{2}$ (open circles), and $\mathrm{X}_{3}$ (closed circles). 
$\mathrm{X}_{3}$ was not detected. On the other hand, $\mathrm{X}_{3}$ was detected in the reactions catalyzed by the mutants. In the case of D263N, $X_{2}$ concentration was higher than that of $X_{3}$ in the reaction mixture, indicating that the hydrolytic activity was higher than the transfer activity. In contrast, $\mathrm{X}_{3}$ concentration was higher than $\mathrm{X}_{2}$ in the reaction with D263C, indicating that transfer activity was higher than hydrolytic activity. The difference is comparable with the remaining hydrolytic activities of the mutants (Table 3 ).

\section{E-3. Mutation at the residue supporting the nucleophilic water molecule (78)}

Conversion of Rex into glycosynthase was successfully performed by mutating the base residue. However, the D263 mutants retained significant hydrolytic activity that decreased the yield of the synthetic product. Moreover, the $\mathrm{F}^{-}$releasing activities of the mutants were much lower than that of the wild type (Table 3). Mutation at the general base residue of an inverting GH could not remove the hydrolytic activity completely because the water molecule retained some activity as a nucleophilic reagent without the aid of the residue. It is, therefore, still important to reduce the hydrolytic activity of glycosynthase obtained from the inverting GHs.

Collins et al. $(72,79)$ found that a mutation at a conserved tyrosine residue (Y203) in pXyl, which shares $32.6 \%$ amino acid identity with Rex, caused a marked decrease in the hydrolytic activity of the enzyme toward xylan. The residue formed a hydrogen bond with a nucleophilic water molecule that formed another hydrogen bond with the general base residue (D281). The pH dependency of the $\mathrm{Y} 203 \mathrm{~F}$ mutant indicated that the tyrosine residue was not a general base, but was important in locating the nucleophilic water at the proper position (79) (Fig. 8). Thus, mutating the corresponding residue of Rex, Y198, confirmed by both the alignment of amino acid sequences and the structural analysis of Rex, was attempted (69).

The $\mathrm{F}^{-}$releasing and hydrolytic activities of the Y198 mutants and/or D263 mutants are presented in Table 3. The mutation at Y198 drastically decreased hydrolytic activity (from 31.2 to $0.06 \mathrm{~s}^{-1}$ ), with a small increase in the $\mathrm{F}^{-}$releasing activity. Furthermore, the $\mathrm{F}^{-}$releasing activity of $\mathrm{Y} 198 \mathrm{~F}$ was 10 times greater than that of the mutants at the general base residue (D263). The $\mathrm{F} / \mathrm{H}$ ratio was 78, approximately 4 times that of D263C, which was the best glycosynthase mutant of the general base residue. A double mutation was also tested. Y198F/D263N showed 20 times less $\mathrm{F}^{-}$releasing activity than $\mathrm{Y} 198 \mathrm{~F}$, but was comparable to that of the corresponding single mutant, $\mathrm{D} 263 \mathrm{~N}$. Though the $\mathrm{F} / \mathrm{H}$ ratio of $\mathrm{Y} 198 \mathrm{~F} / \mathrm{D} 263 \mathrm{~N}$ was twice than that of Y198F, Y198F was considered to be the
この違いは残存する加水分解活性の違いと一致していた。

\section{E-3. 求核触媒水分子を保持する残基への变異 (78)}

Rex のグライコシンターゼへの変換は一般塩基触媒の変 異導入により達成された。しかしながら，D263 変異酵素は有 意な加水分解活性を残存するため結果的に生成物の収率低下 を引き起こしていた。また， $\mathrm{F}^{-}$遊離活性も親酵素に比べて大 きく低下していた（表 3)。真の求核試薬である水分子が酸性 アミノ酸残基による活性化を受けなくともわずかの活性を残 すために, 反転型加水分解酵素では一般塩基触媒残基に変異 を導入しても加水分解活性は完全には除去できないと考えら れる。そのため, 反転型加水分解酵素の加水分解活性を低下 させることは効率的なグライコシンターゼを得るために重要 である。

Collins ら (72,79) は, GH8 エンドキシラナーゼであり Rex とアミノ酸配列上 $32.6 \%$ 相同性を示す $\mathrm{pXyl}$ の GH8 に保 存されているチロシン残基（Y203）に变異を導入することに よりキシランの加水分解活性が大幅に低下することを見いだ した。この残基は一般塩基触媒残基（D281）とともに求核触 媒水分子と水素結合を形成していた。わずかに残存した加水 分解活性を元に測定した $\mathrm{pXyl}-\mathrm{Y} 203 \mathrm{~F}$ 変異酵素の $\mathrm{pH}$-活性曲 線から，Y203 は一般塩基触媒残基ではなく, 触媒水分子を正 しい位置に配位するために重要な残基であることが結論され た (79)。そこで, 一次配列抢よび構造 (69) から同定された Rex の相当残基である Y198（図 8）に対して变異導入を試み た。

$\mathrm{Y} 198$ 単変異酵素と $\mathrm{Y} 198, \mathrm{D} 263$ 二重変異酵素の $\mathrm{F}^{-}$遊離 活性打よび加水分解活性を表 3 に示した。Y198への変異導入 により加水分解活性が劇的に低下した（31.2 $\left.\rightarrow 0.06 \mathrm{~s}^{-1}\right)$ が， $\mathrm{F}^{-}$遊離活性はわずかに増加した。 $\mathrm{Y} 198 \mathrm{~F}$ の $\mathrm{F}^{-}$遊離活性は, 一般塩基触媒残基（D263）変異酵素よりも 10 倍高かった。F $/ \mathrm{H}$ 比は 78 であり, 一般塩基触媒残基の变異で得られる最も 良いグライコシンターゼである $\mathrm{D} 263 \mathrm{C}$ と比較して 4 倍の数值 になった。二重変異酵素では $\mathrm{F}^{-}$遊離活性の低下が見られた。 $\mathrm{Y} 198 \mathrm{~F} / \mathrm{D} 263 \mathrm{~N}$ の $\mathrm{F}^{-}$遊離活性は $\mathrm{Y} 198 \mathrm{~F}$ の 1 / 20 であり, D263N のそれと同程度であった。Y198F/D263C F- 遊離活性 は非常に低かった。 Y198F/D263N の F/H 比は Y198F の二倍 であった。しかしながら， Y198F の F/H 比は生成物の蓄積に 


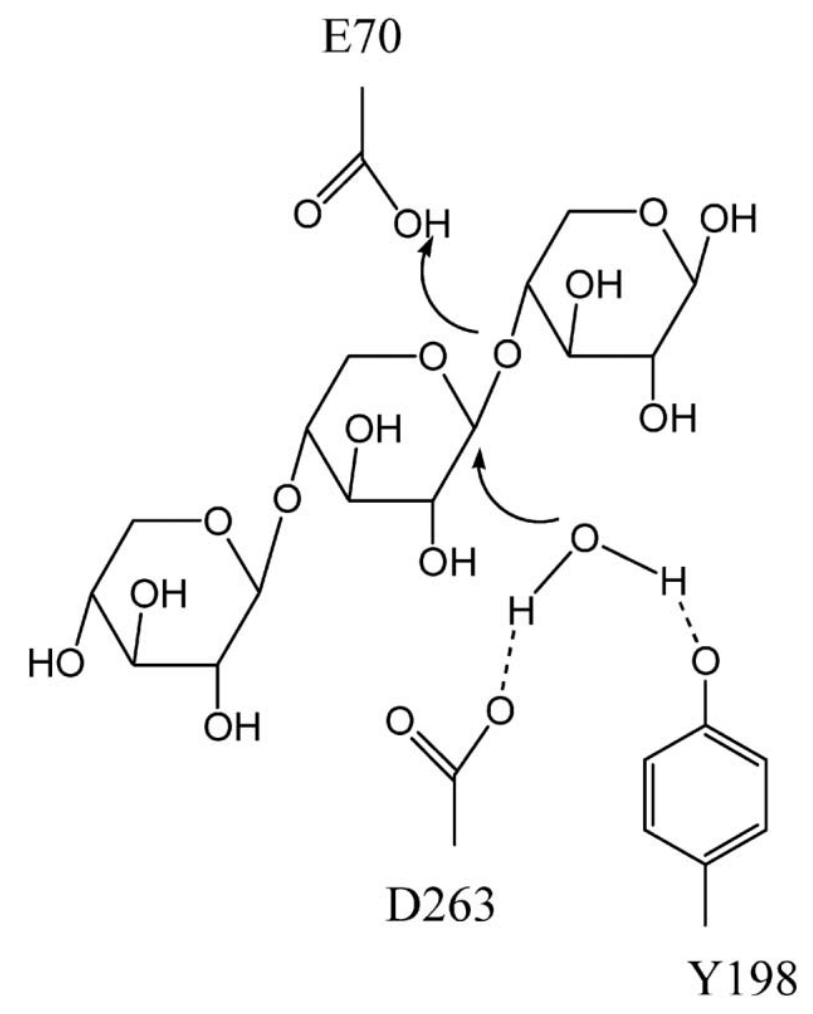

Fig. 8. Schematic description of the catalytic residues of Rex.

best glycosynthase mutant based on the sufficient amount of accumulation of $\mathrm{X}_{3}$ due to its high $\mathrm{F}^{-}$releasing activity and an adequate $\mathrm{F} / \mathrm{H}$ value.

\section{F. Concept to obtain glycosynthase activity from an in- verting GH}

The relationship between the $\mathrm{F}^{-}$releasing activity and the hydrolytic activity of Rex during acquiring the glycosynthase activity was completely different from those in retaining enzymes. In the case of retaining enzymes, the parent enzyme does not possess $\mathrm{F}^{-}$releasing activity $(15,41)$, and a mutation at the base residue completely eliminates the hydrolytic activity because the base residue directly attacks the carbon 1 (C1) of the hydrolyzed glycoside. Thus, while converting retaining GHs into glycosynthases, it is important to acquire $\mathrm{F}^{-}$releasing activity through mutations.

In contrast, the water molecule activated by the base residue attacks the $\mathrm{C} 1$ of the glycoside in inverting enzymes. The mutation of the base residue cannot completely eliminate the hydrolytic activity because the water molecule retains some activity without the aid of the catalytic residue. The parent enzyme possesses $\mathrm{F}^{-}$releasing activity, and the mutations at the base residue cause a decrease in this activity. Thus, to convert inverting GHs
十分な数值でありかつ, $\mathrm{F}^{-}$遊離活性が非常に高いため, Y198F を最も効率的なグライコシンターゼと判断した。

F. 反転型加水分解酵素をグライコシンターゼに変換する設計

Rex のグライコシンターゼ活性の獲得に関する $\mathrm{F}^{-}$遊離活 性と加水分解活性の関係は, 保持型加水分解酵素のものと全 く異なっていた。保持型加水分解酵素では, 親酵素は $\mathrm{F}^{-}$遊離 活性を示さない $(15,41)$ 。また一般塩基触媒残基が求核試薬と して直接アノメリック炭素を攻撃しているために，この残基 の除去により加水分解が完全に除去される。以上のような状 況により, 保持型加水分解酵素では一般塩基触媒残基を変異 させて $\mathrm{F}^{-}$遊離活性の高い変異酵素を探すことが重要である。

対照的に, 反転型加水分解酵素では一般塩基触媒残基に より活性化された水分子が求核試薬として作用しているため に，この残基に变異を入れても活性化されない水分子に幾ば くかの活性が残るために加水分解活性を完全に除去すること ができない。また，親酵素がもともと $\mathrm{F}^{-}$遊離活性を持ってお り, 一般塩基触媒残基への変異導入は $\mathrm{F}^{-}$遊離活性の低下をも たらす。反転型酵素のグライコシンターゼ化に重要なことは $\mathrm{F}^{-}$遊離活性の低下を防ぎながら加水分解活性を最大限低下さ せることである。 
into glycosynthases, it is important to minimize the decrease in $\mathrm{F}^{-}$releasing activity, while maximizing the decrease in hydrolytic activity.

A suggested concept for creating a glycosynthase from an inverting $\mathrm{GH}$ involves mutating a residue holding the nucleophilic water molecule with the general base residue, while keeping the general base residue intact.

\section{G. Glycosynthase from an inverting GH with atypical reaction mechanism}

A second example of a glycosynthase derived from an inverting GH was recently reported to be GH95 $\alpha-1,2-$ L-fucosidase from Bifidobacterium bifidum (AfcA) (80). It is the first report of a glycosynthase from an inverting $\alpha$ glycosidase. This enzyme was the first reported to hydrolyze $\alpha$-1,2-linked L-fucose specifically at the non-reducing end $(81,82)$. No significant identity in the existing amino acid sequences was detected with any other fucosidases, and the enzyme was classified in a new family, GH95. Because $\alpha$-1,2-fucosylated sugars are often found in biologically-functional sugar chains, the enzymatic production of such compounds are desired. However, the enzyme is an inverting enzyme and no transglycosylation
以上のことから，反転型加水分解酢素をグライコシン ターゼに変換するために, 求核試薬として作用する水分子を 一般塩基触媒残基と共に保持する残基に変異を導入し一般塩 基触媒残基には変異を導入しないような分子設計を行えば良 いと結論した。反転型加水分解酵素のグライコシンターゼに 変換するための分子設計が可能になったことから，今後これ らの酵素のグリコシド合成への応用が期待される。

\section{G. 標準的でない反応機構を示す反転型加水分解酵素のグライ} コシンターゼ化

反転型加水分解酵素の二例目は, GH95 に属する $B i-$ fidobacterium bifidum 由来 $\alpha-1,2-\mathrm{L}-$ フコシダーゼ（AfcA）で 報告された $(80)$ 。これは, 反転型 $\alpha$ グリコシダーゼ由来グラ イコシンターゼの最初の報告である。この酵素は, 非還元末

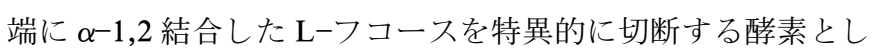
て報告された $(81,82)$ 。他の $\alpha$-フコシダーゼと相同性を示さ ず，当時新規なファミリーGH95に分類された。非還元末端 が $\alpha-1,2$ フコシル化された構造は, 生化学的に重要な糖鎖に しばしば見られるため,このような糖鎖の酵素的合成法の開 発が望まれていた。しかしながら AfcA は反転型酵素であり 糖転移活性は検出されなかった。

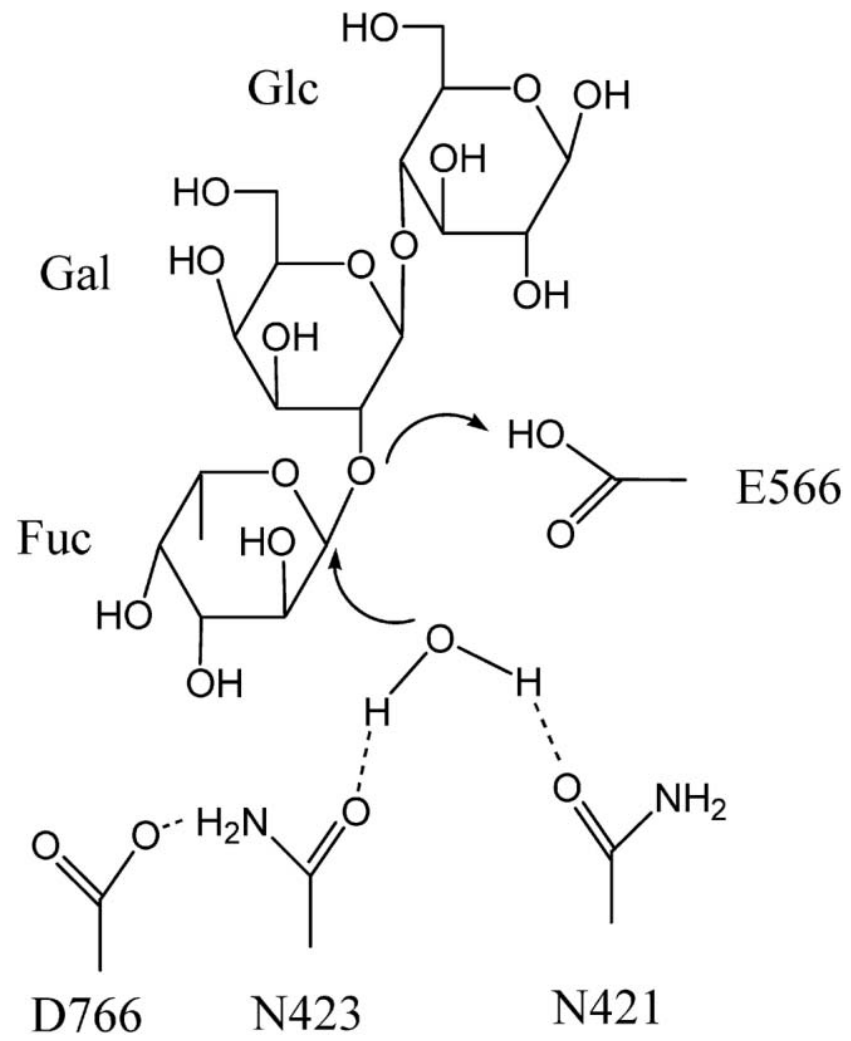

Fig. 9. Schematic description of the catalytic residues of AfcA. 
activity was detected.

Structural analysis of AfcA revealed that the reaction mechanism was different from typical inverting GHs (83). AfcA has an acidic proton donor residue, E566, similar to typical inverting GHs; however, the base residue activating the nucleophilic water is not an acidic amino acid, but an asparagine residue, N423, that is activated by an acidic residue, D766. The catalytic water residue is held by another asparagine residue, N421, apart from N423 (Fig. 9).

These three residues were mutated to glycine and the glycosynthase activities were examined by using betafucosyl fluoride as the donor and lactose as the acceptor. The product was detected significantly only in the D766G mutant. The structure of the product was determined to be $2^{\prime}$-fucosyllactose as expected from the specificity of AfcA (80).

In this case, the residue mutated (D766) was not the residue holding the catalytic water molecule with the base residue (N421). Instead, the mutation of the residue activating the base residue was changed, while the base residue, N423, was kept intact. Though the catalytic mechanism of AfcA is different from other typical inverting GHs, it should be noted that the base residue should be intact to obtain the best glycosynthase mutant.

\section{Acknowledgements}

This work was supported in part by a grant from the Program for Promotion of Basic Research Activities for Innovative Biosciences (PROBRAIN), Tokyo, Japan.
AfcA の構造解析の結果から, 本酥素の触媒メカニズムは 典型的な反転型加水分解酵素のものとは異なっていることが 示された(83)。AfcA は酸性アミノ酸残基 E566をプロトン供 与基として抢り, この点は通常の反転型加水分解酵素と同様 である。一般塩基触媒残基は通常と異なり酸性アミノ酸残基 ではなくアスパラギン N423であり，この残基は酸性アミノ酸 残基 D766 により活性化されていた。求核試薬として作用する 水は N423 と共にもう一つのアスパラギン残基 N421 により保 持されていた（図 9)。

これらの3 残基をそれぞれグリシンに变換した変異酵素 を作製し， $\beta$-フコシルフルオリドをドナーとしラクトースを アクセプターとした反応を調べた。その結果， D766G に最も 強い生成物の蓄積が観測された。生成物は, AfcA の基質特異 性から予測されると抢り 2'ーフコシルラクトースであった $(80) 。$ この場合有効な変異は一般塩基触媒残基と共に水を保持す る残基（N421）ではなく，一般塩基触媒残基を活性化してい る残基（D766）であった。AfcAの触媒機構は通常の反転型 加水分解酵素とは異なるが，一般塩基触媒残基を残したまま それに関わる残基に変異を導入することによりグライコシン ターゼ化を達成したことは共通する点である。

\section{References}

1. Nishimoto, M., and Kitaoka, M. (2007) Biosci. Biotechnol. Biochem. 71, 2101-2104

2. Totani, K., Yasutake, N., Murata, T., and Usui, T. (2004) Trends Glycosci. Glycotechnol. 16, 383-392

3. Liu, Z., Lu, Y., Zhang, J., Pardee, K., and Wang, P. G. (2003) Appl. Environ. Microbiol. 69, 2110-2115

4. Koizumi, S. (2003) Trends Glycosci. Glycotechnol. 15, 65-74

5. Kitaoka, M., and Hayashi, K. (2002) Trends Glycosci. Glycotechnol. 14, 35-50

6. Murata, T., and Usui, T. (2000) Trends Glycosci. Glycotechnol. 12, 161-174

7. Henrissat, B., and Bairoch, A. (1996) Biochem. J. 316, 695-696

8. Davies, G., and Henrissat, B. (1995) Structure 3, 853-859

9. Henrissat, B., and Bairoch, A. (1993) Biochem. J. 293, 781-788

10. Henrissat, B. (1991) Biochem. J. 280, 309-316

11. Sinnott, M. L. (1990) Chem. Rev. 90, 1171-1202

12. Nakakuki, T. (2003) Trends Glycosci. and Glycotechnol. 15, 57-64

13. Hehre, E. J., Brewer, C. F., and Genghof, D. S. (1979) J. Biol. Chem. 254, 5942-5950

14. Becker, D., Johnson, K. S., Koivula, A., Schulein, M., and Sinnott, M. L. (2000) Biochem. J. 345, 315-319

15. Williams, S. J., and Withers, S. G. (2000) Carbohydr. Res. 327, 27-46

16. Matsui, H., Blanchard, J. S., Brewer, C. F., and Hehre, E. J. (1989) J. Biol. Chem. 264, 8714-8716

17. Nakano, M., Brewer, C. F., Kasumi, T., and Hehre, E. J. (1989) Carbohydr. Res. 194, 139-144

18. Kasumi, T., Tsumuraya, Y., Brewer, C. F., Kersters-Hilderson, H., Claeyssens, M., and Hehre, E. J. (1987) Biochemistry 26, 3010-3016

19. Kasumi, T., Brewer, C. F., Reese, E. T., and Hehre, E. J. (1986) Carbohydr. Res. 146, 39-49

20. Hehre, E. J., Sawai, T., Brewer, C. F., Nakano, M., and Kanda, T. (1982) Biochemistry 21, 3090-3097

21. Konstantinidis, A. K., Marsden, I., and Sinnott, M. L. (1993) Biochem. J. 291, 883-888

22. Kitahata, S., Brewer, C. F., Genghof, D. S., Sawai, T., and Hehre, E. J. (1981) J. Biol. Chem. 256, 6017-6026

23. Jakeman, D. L., and Withers, S. G. (2002) Trends Glycosci. Glycotechnol. 14, 13-25 
24. MacKenzie, L. F., Wang, Q. P., Warren, R. A. J., and Withers, S. G. (1998) J. Am. Chem. Soc. 120, 5583-5584

25. Tao, H., Peralta-Yahya, P., Decatur, J., and Cornish, V. W. (2008) Chembiochem 9, 681-684

26. Wilkinson, S. M., Liew, C. W., Mackay, J. P., Salleh, H. M., Withers, S. G., and McLeod, M. D. (2008) Org. Lett. 10, $1585-1588$

27. Wang, L. X. (2008) Carbohydr. Res. 343, 1509-1522

28. Shaikh, F. A., and Withers, S. G. (2008) Biochem. Cell Biol. 86, 169-177

29. Ben-David, A., Shoham, G., and Shoham, Y. (2008) Chem. Biol. 15, 546-551

30. Marton, Z., Tran, V., Tellier, C., Dion, M., Drone, J., and Rabiller, C. (2008) Carbohydr. Res. 343, 2939-2946

31. Faijes, M., and Planas, A. (2007) Carbohydr. Res. 342, 1581-1594

32. Blanchard, S., Armand, S., Couthino, P., Patkar, S., Vind, J., Samain, E., Driguez, H., and Cottaz, S. (2007) Carbohyd.r Res. 342, 710-716

33. Yang, M., Davies, G. J., and Davis, B. G. (2007) Angew. Chem. Int. Ed. Engl. 46, 3885-3888

34. Hommalai, G., Withers, S. G., Chuenchor, W., Cairns, J. R., and Svasti, J. (2007) Glycobiology 17, 744-753

35. Ben-David, A., Bravman, T., Balazs, Y. S., Czjzek, M., Schomburg, D., Shoham, G., and Shoham, Y. (2007) Chembiochem 8, 2145-2151

36. Piens, K., Henriksson, A. M., Gullfot, F., Lopez, M., Faure, R., Ibatullin, F. M., Teeri, T. T., Driguez, H., and Brumer, H. (2007) Org. Biomol. Chem. 5, 3971-3978

37. Mullegger, J., Chen, H. M., Warren, R. A., and Withers, S. G. (2006) Angew. Chem. Int. Ed. Engl. 45, 2585-2588

38. Vaughan, M. D., Johnson, K., DeFrees, S., Tang, X., Warren, R. A., and Withers, S. G. (2006) J. Am. Chem. Soc. 128, $6300-6301$

39. Kim, Y. W., Fox, D. T., Hekmat, O., Kantner, T., McIntosh, L. P., Warren, R. A., and Withers, S. G. (2006) Org. Biomol. Chem. 4, 2025-2032

40. Faijes, M., Saura-Valls, M., Perez, X., Conti, M., and Planas, A. (2006) Carbohydr. Res. 341, 2055-2065

41. Sugimura, M., Nishimoto, M., and Kitaoka, M. (2006) Biosci. Biotechnol. Biochem. 70, 1210-1217

42. Faure, R., Saura-Valls, M., Brumer, H., 3rd, Planas, A., Cottaz, S., and Driguez, H. (2006) J. Org. Chem. 71, 5151-5161

43. Tao, H., Peralta-Yahya, P., Lin, H., and Cornish, V. W. (2006) Bioorg. Med. Chem. 14, 6940-6953

44. Hancock, S. M., Vaughan, M. D., and Withers, S. G. (2006) Curr. Opin. Chem. Biol. 10, 509-519

45. Drone, J., Feng, H.-y., Tellier, C., Hoffmann, L., Tran, V., Rabiller, C., and Dion, M. (2005) Eur. J. Org. Chem. 2005, 1997-1983

46. Trincone, A., Giordano, A., Perugino, G., Rossi, M., and Moracci, M. (2005) Chembiochem 6, 1431-1437

47. Kim, Y. W., Chen, H., and Withers, S. G. (2005) Carbohydr. Res. 340, 2735-2741

48. Daines, A. M., Maltman, B. A., and Flitsch, S. L. (2004) Curr. Opin. Chem. Biol. 8, 106-113

49. Watts, A. G., and Withers, S. G. (2004) Biochem. J. 380, e9-10

50. Kim, Y. W., Lee, S. S., Warren, R. A., and Withers, S. G. (2004) J. Biol. Chem. 279, 42787-42793

51. Lin, H., Tao, H., and Cornish, V. W. (2004) J. Am. Chem. Soc. 126, 15051-15059

52. van Lieshout, J., Faijes, M., Nieto, J., van der Oost, J., and Planas, A. (2004) Archaea 1, 285-292

53. Fairweather, J. K., Hrmova, M., Rutten, S. J., Fincher, G. B., and Driguez, H. (2003) Chemistry 9, 2603-2610

54. Jahn, M., Stoll, D., Warren, R. A., Szabo, L., Singh, P., Gilbert, H. J., Ducros, V. M., Davies, G. J., and Withers, S. G. (2003) Chem Commun (Camb), 1327-1329

55. Ducros, V. M., Tarling, C. A., Zechel, D. L., Brzozowski, A. M., Frandsen, T. P., von Ossowski, I., Schulein, M., Withers, S. G., and Davies, G. J. (2003) Chem. Biol. 10, 619-628

56. Trincone, A., Giordano, A., Perugino, G., Rossi, M., and Moracci, M. (2003) Bioorg. Med. Chem. Lett. 13, 4039-4042

57. Faijes, M., Perez, X., Perez, O., and Planas, A. (2003) Biochemistry 42, 13304-13318

58. Jakeman, D. L., and Withers, S. G. (2002) Can. J. Chem. 80, 866-870

59. Hrmova, M., Imai, T., Rutten, S. J., Fairweather, J. K., Pelosi, L., Bulone, V., Driguez, H., and Fincher, G. B. (2002) J. Biol.Chem. 277, 30102-30111

60. Okuyama, M., Mori, H., Watanabe, K., Kimura, A., and Chiba, S. (2002) Biosci. Biotechnol. Biochem. 66, 928-933

61. Tolborg, J. F., Petersen, L., Jensen, K. J., Mayer, C., Jakeman, D. L., Warren, R. A., and Withers, S. G. (2002) J. Org. Chem. 67, 4143-4149

62. Fairweather, J. K., Faijes, M., Driguez, H., and Planas, A. (2002) Chembiochem 3, 866-873

63. Nashiru, O., Zechel, D. L., Stoll, D., Mohammadzadeh, T., Warren, R. A., and Withers, S. G. (2001) Angew. Chem. Int. Ed. Engl. 40, 417-420

64. Mayer, C., Jakeman, D. L., Mah, M., Karjala, G., Gal, L., Warren, R. A., and Withers, S. G. (2001) Chem. Biol. 8, 437-443

65. Brun, E., Brumer, H., 3rd, MacKenzie, L. F., Withers, S. G., and McIntosh, L. P. (2001) J. Biomol. NMR 21, 67-68

66. Mayer, C., Zechel, D. L., Reid, S. P., Warren, R. A., and Withers, S. G. (2000) FEBS Lett. 466, 40-44

67. Trincone, A., Perugino, G., Rossi, M., and Moracci, M. (2000) Bioorg. Med. Chem. Lett. 10, 365-368

68. Malet, C., and Planas, A. (1998) FEBS Lett. 440, 208-212

69. Fushinobu, S., Hidaka, M., Honda, Y., Wakagi, T., Shoun, H., and Kitaoka, M. (2005) J. Biol. Chem. 280, 17180-17186

70. Honda, Y., Fushinobu, S., Hidaka, M., Wakagi, T., Shoun, H., and Kitaoka, M. (2005) Acta Crystallogr. Sect. F Struct. Biol. Cryst. Commun. 61, 291-292

71. Honda, Y., and Kitaoka, M. (2004) J. Biol. Chem. 279, 55097-55103

72. Collins, T., Meuwis, M. A., Stals, I., Claeyssens, M., Feller, G., and Gerday, C. (2002) J. Biol. Chem. 277, 35133-35139

73. Van Petegem, F., Collins, T., Meuwis, M. A., Gerday, C., Feller, G., and Van Beeumen, J. (2003) J Biol Chem 278, $7531-7539$

74. Guerin, D. M., Lascombe, M. B., Costabel, M., Souchon, H., Lamzin, V., Beguin, P., and Alzari, P. M. (2002) J. Mol. Biol. 316, 1061-1069 
75. Takami, H., Nakasone, K., Takaki, Y., Maeno, G., Sasaki, R., Masui, N., Fuji, F., Hirama, C., Nakamura, Y., Ogasawara, N., Kuhara, S., and Horikoshi, K. (2000) Nucleic Acids Res. 28, 4317-4331

76. Shintate, K., Kitaoka, M., Kim, Y. K., and Hayashi, K. (2003) Carbohydr. Res. 338, 1981-1990

77. Honda, Y., and Kitaoka, M. (2006) J. Biol. Chem. 281, 1426-1431

78. Honda, Y., Fushinobu, S., Hidaka, M., Wakagi, T., Shoun, H., Taniguchi, H., and Kitaoka, M. (2008) Glycobiology 18, 325-330

79. Collins, T., De Vos, D., Hoyoux, A., Savvides, S. N., Gerday, C., Van Beeumen, J., and Feller, G. (2005) J. Mol. Biol. 354, $425-435$

80. Wada, J., Honda, Y., Nagae, M., Kato, R., Wakatsuki, S., Katayama, T., Taniguchi, H., Kumagai, H., Kitaoka, M., and Yamamoto, K. (2008) FEBS Lett. 582, 3739-3743

81. Katayama, T., Sakuma, A., Kimura, T., Makimura, Y., Hiratake, J., Sakata, K., Yamanoi, T., Kumagai, H., and Yamamoto, K. (2004) J. Bacteriol. 186, 4885-4893

82. Katayama, T., Fujita, K., and Yamamoto, K. (2005) J. Biosci. Bioeng. 99, 457-465

83. Nagae, M., Tsuchiya, A., Katayama, T., Yamamoto, K., Wakatsuki, S., and Kato, R. (2007) J. Biol. Chem. 282, 18497-18509

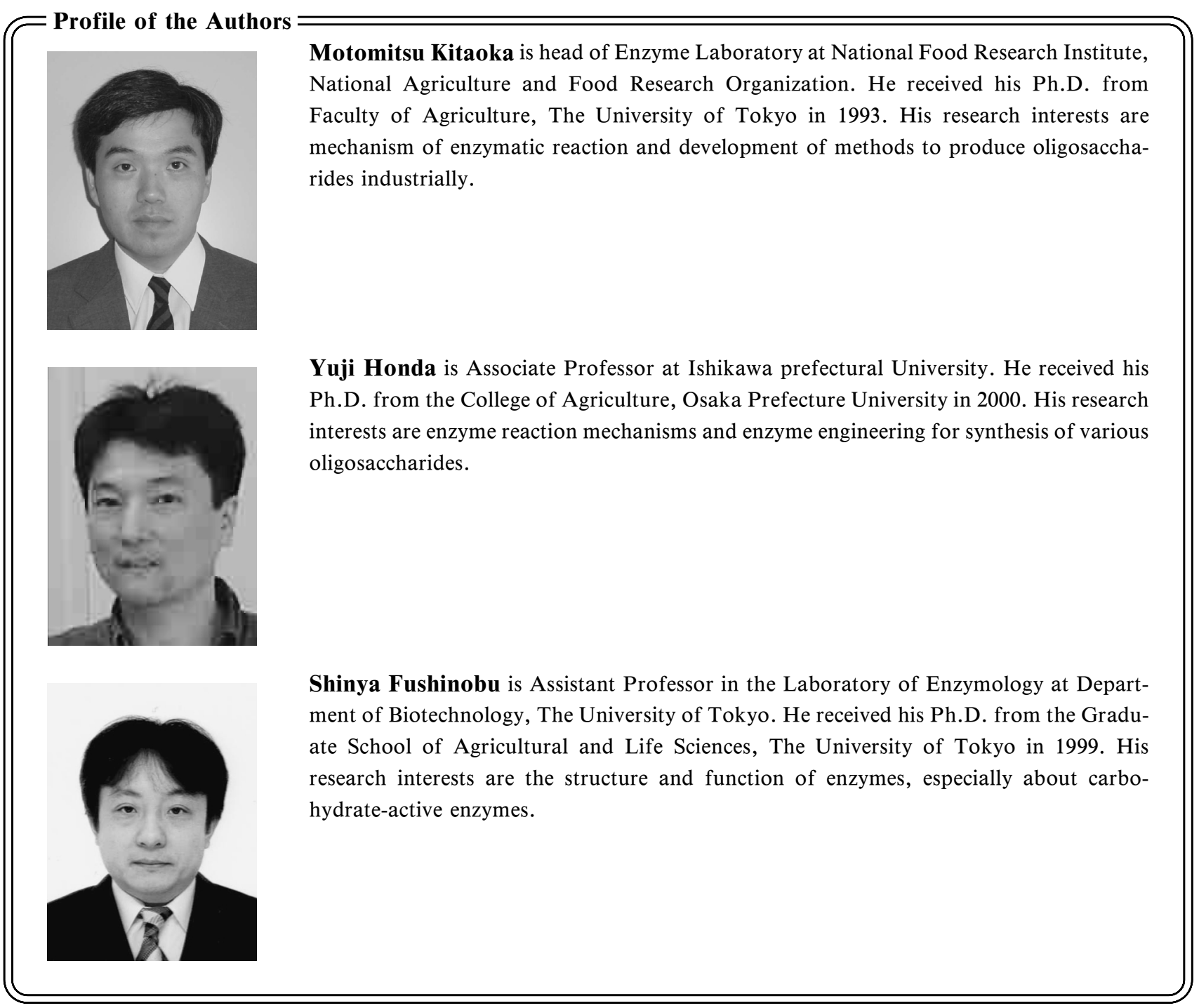




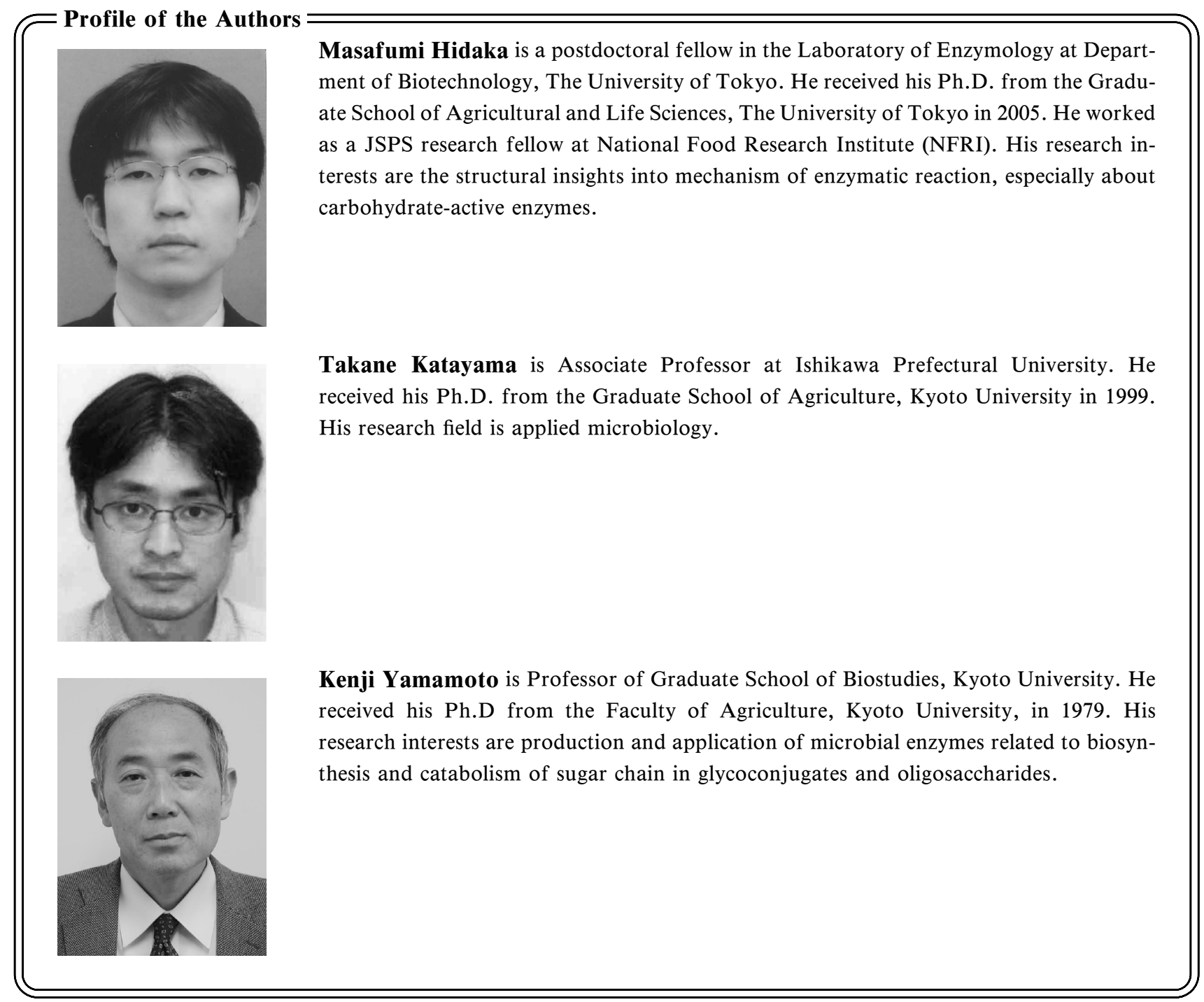

